\title{
Organismal biology joins climate research: the example of ENSO
}

\author{
Sven Thatje
}

Published online: 19 January 2008

(C) Springer-Verlag and AWI 2008

El Niño Southern Oscillation (ENSO) is a climate oscillation affecting the Humboldt Current upwelling system off Pacific South America. ENSO constitutes the major intradecadal climate variability along the upwelling system of Pacific South America and is known to be of global impact (Thiel et al. 2007). It represents an interannual variation between a warm phase (El Niño: EN) and a cold phase (La Niña: LN) occurring at intervals of 2-10 years. Both EN and LN are impacting the abundance and availability of distinct coastal marine resources off Pacific South America with often-catastrophic consequences for the socio-economy of the countries involved (Glantz 1984; Arntz and Fahrbach 1991). Some of the best data available on the impact of EN resulted from the EN 1982-83 (Barber and Chavez 1983; Arntz and Fahrbach 1991; Chavez et al. 1999; Tarazona et al. 2001). However, when trying to reveal the development and resilience potential of coastal marine communities, the lack or inaccessibility of information is a general concern (Thatje et al. 2007; Riascos et al. 2008). Most studies on the biology and ecology of organisms occurring in upwelling regions are of descriptive nature and underlying processes that are driven by ENSO are far from being understood (Criales-Hernández et al. 2008; Sotil et al. 2008), which hampers the development of (short-term) predictive or response-management of key resources (Taylor et al. 2008).

Special Issue: Climate variability and El Niño Southern Oscillation: implications for natural coastal resources and management. S. Thatje (ed.).

S. Thatje $(\bowtie)$

National Oceanography Centre, Southampton,

School of Ocean and Earth Science, University of Southampton,

European Way, Southampton SO14 3ZH, United Kingdom

e-mail: svth@noc.soton.ac.uk
During EN, the displacement of species over more than $10^{\circ}$ of latitude (Arntz and Fahrbach 1991; Ashton et al. 2008), together with the incursion of exotic species (Tarazona and Arntz 2001), poses new challenges to artisanal fisheries. Changes in oceanographic features such as the variable intensity of upwelling during EN generate changes in the food web that, depending on the intensity of the event, can alter and restructure benthic communities (Wolff and Mendo 2000; Hidalgo et al. 2008; Moreno et al. 2008; Villegas et al. 2008) and populations (Riascos et al. 2008), species diversity and composition, as well as life history traits (Oliva et al. 2008), and ultimately lead to the collapse of entire populations. However, on microecological scale, effects of EN are not necessarily negative, but can foster community biomass of commercial key species (Arntz and Fahrbach 1991) due to decreasing hypoxia within the oxygen minimum zone (Escribano et al. 2004). In transitional biogeographic areas that are not within the primary impact area of EN, communities can seemingly remain unaffected at all, if oxygen limitation is not a general constraint (Laudien et al. 2007).

The project "Climate Variability and El Niño Southern Oscillation: Implications for Natural Coastal Resources and Management" (CENSOR) is funded within the FP6-INCO Programme of the European Commission. CENSOR targets the study of ENSO effects on near-shore coastal environments and related socio-economics along Pacific South America (Thatje et al. 2008). The present Special Issue of Helgoland Marine Research gives an overview of various scientific areas tackled within the project rather than aiming for an integrated view of the ecosystem and management problems associated with ENSO in Pacific South America (Taylor et al. 2008; Thatje et al. 2008). The compilation of ongoing work clearly marks the complexity of the Humboldt Current ecosystem in response to both EN and LN, 
which complicates management solutions given the multiple demands on this coastal ecosystem by various societal groups, including different socio-economic systems of the adjacent countries (for discussion, see Nauen et al. 2006; Thatje et al. 2008). As a result, it becomes obvious that a management for sustainability of coastal areas within this upwelling system does rather depend on locally adapted and flexible small-scale management approaches; management approaches that cannot simply transfer experiences made with macro-economic management attempts [i.e. individual transferable quotas (ITQ) in fisheries]. Multidisciplinary studies centered on organismal research remain the key to our increased understanding of the response of coastal species of interest to artisanal resource users to ENSO. The impact of such studies for possible mitigation of climate effects on marine ecosystems and the analysis of options for the human communities affected tends to be underrated. Since the intensity and onset of EN and thus its impact on Pacific South America strongly varies (Arntz and Fahrbach 1991), management advice tailored to small-scale users is necessary (i.e. Taylor et al. 2008; Thatje et al 2008) to evaluate the variable responses of coastal ecosystems along Pacific South America to climate oscillation, particularly as they have much less destructive track records of resource use than industrial-scale operations, at least unless they are forced into direct competition.

\section{Reviewers for volume 62(1)}

Arreguin-Sánchez, Francisco, Centro Interdisciplinario de Ciencias Marinas, La Paz

Bertness, Mark D., Brown University, Providence

Brey, Thomas, Alfred-Wegener-Institut, Bremerhaven

Calcagno, Javier A. Universidad de Buenos Aires

Escribano, Rubén, COPAS, Concepción

Geiger, Stephen P., Fish and Wildlife Research Institute,

St Petersburg, FL

Giménez, Luis, University of Wales, Bangor

Graham, Michael, Moss Landing Marine Laboratories

Gutierrez, Nicolás L., University of Washington

Held, Christoph, Alfred-Wegener-Institut, Bremerhaven

Heilmayer, Olaf, National Oceanography Centre,

Southampton

Jacob, Ute, University of Cork

Jenkins, Stuart R., University of Wales, Bangor

Johnson, Mark, The Queen's University of Belfast

Laudien, Jürgen, Alfred-Wegener-Institut, Bremerhaven

Lovrich, Gustavo A., Centro Austral de Investigaciones Científicas, Ushuaia

Lucas, Cathy, National Oceanography Centre, Southampton

Luque, José L., Otago University, New Zealand

Maeda-Martínez, Alfonso, CIBNOR, La Paz
Montiel, Américo, Universidad de Magallanes, Punta Arenas Nauen, Cornelia E., European Commission, Brussels

Raupach, Michael, Museum König, Bonn

Schejter, Laura, INIDEP, Mar del Plata

Schwamborn, Ralf, Alfred-Wegener-Institut, Bremerhaven

Silliman, Brian S., University of Florida, Gainesville

Tarazona, Juan, Universidad San Marcos, Lima

Thiel, Martin, Universidad Católica del Norte, Coquimbo

Timi, Juan, Universidad de Mar del Plata

Vasquez, Julio, Universidad Católica del Norte, Coquimbo

\section{Contributions to the volume "Climate Variability and EI Niño Southern Oscillation: Implications for Natural Coastal Resources and Management" (in alphabetic order)}

Ashton T, Riascos JM, Pacheco A (2008) First record of Cymatium keenae Beu, 1970 (Mollusca: Ranellidae) from Antofagasta Bay, northern Chile, in connection with El Niño events. Helgol Mar Res. doi:10.1007/ s10152-007-0084-5

Criales-Hernández MI, Schwamborn R, Graco M, Ayón P, Hirche H-J, Wolff M (2008) Zooplankton vertical distribution and migration off central Peru in relation to the oxygen minimum layer. Helgol Mar Res. doi:10.1007/ s10152-007-0094-3

Hidalgo FJ, Firstater FN, Fanjul E, Cielo Bazterrica M, Lomovasky BJ, Tarazona J, Iribarne OO (2008) Grazing effects of the periwinkle Echinolittorina peruviana at a central Peruvian high rocky intertidal. Helgol Mar Res. doi:10.1007/s10152-007-0086-3

Moreno RA, Badano EI, Sepulveda RD, Thatje S, Rozbaczylo N, Carrasco FD (2008) Subtidal macrozoobenthos communities from northern Chile during and post El Niño 1997-98. Helgol Mar Res. doi:10.1007/s10152007-0095-2

Oliva ME, Barrios I, Thatje S, Laudien J (2008) Changes in prevalence and intensity of infection of Profilicollis altmani (Perry, 1942) cystacanth (Acanthocephala) parasitizing the mole crab Emerita analoga (Stimpson, 1857): an El Niño cascade effect? Helgol Mar Res. doi:10.1007/ s10152-007-0082-7

Riascos JM, Heilmayer O, Laudien J (2008) Population dynamics of the tropical bivalve Cardita affinis from Málaga Bay, Colombian Pacific related to La Niña 1999-2000. Helgol Mar Res. doi:10.1007/s10152-0070083-6

Sotil G, Tarazona J, Alvis R, Francia JC, Shiga B (2008) Comparative evaluation of the DNA damage response in two Peruvian marine bivalves exposed to temperature changes. Helgol Mar Res. doi:10.1007/s10152-0070100-9 
Taylor M, Wolff M, Vadas F, Yamashiro C (2008) Trophic and environmental drivers of the Sechura Bay Ecosystem (Peru) over an ENSO cycle. Helgol Mar Res. doi:10.1007/s10152-007-0093-4

Thatje S (2008) Organismal biology joins Climate Research: the example of ENSO. Helgol Mar Res. doi:10.1007/s10152-007-0098-z

Thatje S, Heilmayer O, Laudien J (2008) Climate variability and El Niño Southern Oscillation: Implications for Natural Coastal Resources and Management. Helgol Mar Res. doi:10.1007/s10152-008-0104-0

Villegas MJ, Laudien J, Sielfeldt W, Arntz WE (2008) Macrocystis integrifolia and Lessonia trabeculata (Laminariales; Phaeophyceae) kelp habitat structures and associated macrobenthic community off northern Chile. Helgol Mar Res. doi:10.1007/s10152-007-0096-1

Acknowledgments On behalf of the CENSOR Consortium I would like to thank the European Commission and the Chilean CONICYT for supporting our work. I am especially indebted to the help by many colleagues who functioned as reviewers to the work published in this Special Issue of Helgoland Marine Research. My sincere thanks go to Julie Cunningham for her assistance in editorial work. This work was funded in the frame of the FP6 EU-project CENSOR (Climate Variability and El Niño Southern Oscillation: Implications for Natural Coastal Resources and Management, contract 511071) (www.censor.name) and the Programa Bicentenario de Ciéncia y Tecnología CONICYT-CENSOR-RUE02, and is CENSOR publication number 0337 . Without administrative support and commitment by the Alfred Wegener Institute the realization of this project would have been hardly possible. I am personally indebted to AWI's former Administrative Director Dr. Rainer Paulenz for his great support. Professor Dr. Heinz-Dieter Franke and Springer are thanked for making this Special Issue possible.

\section{References}

Arntz WE, Fahrbach E (1991) El Niño - Klimaexperiment der Natur. Birkhäuser Verlag, Basel (Switzerland), pp 264

Ashton T, Riascos JM, Pacheco A (2008) First record of Cymatium keenae Beu, 1970 (Mollusca: Ranellidae) from Antofagasta Bay, northern Chile, in connection with El Niño events. Helgol Mar Res. doi:10.1007/s 10152-007-0084-5

Barber RT, Chavez FP (1983) Biological consequences of El Niño. Science 222:1203-1210

Chavez FP, Strutton PG, Friedrich GE, Feely RA, Feldman GA, Foley D, McPhaden MJ (1999) Biological and chemical response to the equatorial Pacific Ocean to the 1997 and 1998 El Niño. Science 286:2126-2131

Criales-Hernández MI, Schwamborn R, Graco M, Ayón P, Hirche H-J, Wolff M (2008) Zooplankton vertical distribution and migration off central Peru in relation to the oxygen minimum layer. Helgol Mar Res. doi:10.1007/s10152-007-0094-3

Escribano R, Daneri G, Farías L, Gallardo VA, González HE, Gutierrez D, Lange CB, Morales CE, Pizarro O, Ulloa O, Braun M (2004) Biological and chemical consequences of the 19971998 El Niño in the Chilean coastal upwelling system: a synthesis. Deep Sea Res II 51:2389-2411

Glantz MH (1984) Floods, fires and famine: Is El Niño to blame? Oceanus 27:14-20
Hidalgo FJ, Firstater FN, Fanjul E, Cielo Bazterrica M, Lomovasky BJ, Tarazona J, Iribarne OO (2008) Grazing effects of the periwinkle Echinolittorina peruviana at a central Peruvian high rocky intertidal. Helgol Mar Res. doi:10.1007/s10152-007-0086-3

Laudien J, Rojo M, Oliva M, Arntz WE, Thatje S (2007) Sublittoral soft bottom communities and diversity of Mejillones Bay in northern Chile (Humboldt Current upwelling system). Helgol Mar Res 61:103-116

Moreno RA, Badano EI, Sepulveda RD, Thatje S, Rozbaczylo N, Carrasco FD (2008) Subtidal macrozoobenthos communities from northern Chile during and post El Niño 1997-98. Helgol Mar Res. doi:10.1007/s10152-007-0095-2

Nauen CE, Christensen V, Failler P, Opitz S, Thatje S (2006) Recovering fisheries from crisis or collapse: how to shorten impact time of international research cooperation. 13 pages. In: Proceedings of the thirteenth biennial conference of the International Institute of Fisheries Economics \& Trade, July 11-14, 2006, Portsmouth, UK: Rebuilding Fisheries in an Uncertain Environment. Compiled by Ann L. Shriver. International Institute of Fisheries Economics \& Trade, Corvallis, Oregon, USA, 2006. CD ROM. ISBN 0-9763432-3-1

Oliva ME, Barrios I, Thatje S, Laudien J (2008) Changes in prevalence and intensity of infection of Profilicollis altmani (Perry, 1942) cystacanth (Acanthocephala) parasitizing the mole crab Emerita analoga (Stimpson, 1857): an El Niño cascade effect? Helgol Mar Res. doi:10.1007/s10152-007-0082-7

Riascos JM, O Heilmayer, J Laudien (2008) Population dynamics of the tropical bivalve Cardita affinis from Málaga Bay, Colombian Pacific related to La Niña 1999-2000. Helgol Mar Res. doi:10.1007/s10152-007-0083-6

Sotil G, Tarazona J, Alvis R, Francia JC, Shiga B (2008) Comparative evaluation of the DNA damage response in two Peruvian marine bivalves exposed to temperature changes. Helgol Mar Res. doi:10.1007/s10152-007-0100-9

Tarazona J, Arntz WE (2001) The Peruvian coastal upwelling system. Ecol Stud 144:29-244

Tarazona J, Arntz W, Valle S, Peña T (2001) Los indices de El Niño y del impacto sobre las comunidades bentónicas. In: Tarazona J, Arntz W, Castillo E (eds) El Niño en America Latina: impactos biológicos y sociales. CONCYTEC, Lima, pp 113-125

Taylor M, Wolff M, Vadas F, Yamashiro C (2008) Trophic and environmental drivers of the Sechura Bay Ecosystem (Peru) over an ENSO cycle. Helgol Mar Res. doi:10.1007/s10152-007-0093-4

Thatje S, Laudien J, Heilmayer O, Nauen CE (2007) Understanding El Niño - The importance of Grey Literature in coastal ecosystem research and management. Mar Policy 31:85-93

Thatje S, Heilmayer O, Laudien J (2008) Climate variability and El Niño Southern Oscillation: implications for natural coastal resources and management. Helgol Mar Res. doi:10.1007/s10152008-0104-0

Thiel M, Macaya EC, Arntz WE, Bastias H, Brokordt K, Camus PA, Castilla JC, Castro LR, Cortes M, Dumont CP, Escribano R, Fernandez M, Gajardo JA, Gaymer CF, Gomez I, Gonzalez AE, Gonzalez HE, Haye PA, Illanes JE, Iriarte JL, Lancellotti DA, Luna-Jorquera G, Luxordo C, Manriquez PH, Marin V, Muños P, Navarrete SA, Perez E, Poulin E, Sellanes J, Sepulveda HH, Stotz W, Tala F, Thomas A, Vargas CA, Vasquez JA, Vega JMA (2007) The Humboldt Current System of northern and central Chile. Oceanogr Mar Biol Ann Rev 45:195-345

Villegas MJ, Laudien J, Sielfeldt W, Arntz WE (2008) Macrocystis integrifolia and Lessonia trabeculata (Laminariales; Phaeophyceae) kelp habitat structures and associated macrobenthic community off northern Chile. Helgol Mar Res. doi:10.1007/ s10152-007-0096-1

Wolff M, Mendo J (2000) Management of the Peruvian bay scallop (Argopecten purpuratus) metapopulation with regard to environmental change. Aquat Conserv 10:117-126 